\title{
Transdisciplinary Reflections on Glăveanu's “Crisis” of the Psychology of Creativity
}

\author{
Alfonso Montuori \\ California Institute of Integral Studies, USA \\ E-mail address: amontuori@ciis.edu
}

\section{ARTICLE INFO}

\section{Keywords:}

Transdisciplinarity

Creative inquiry

Epistemological assumptions

Article history:

Received 16 November 2014

Received in revised form 24 December 2014

Accepted 27 December 2014

\section{A B STRACT}

ISSN: 2354-0036

DOI: 10.15290/ctra.2014.01.02.12

Vlad Glăveanu's essay, in which he argues that creativity research, and specifically the psychology of creativity, is a discipline in crisis, is a welcome breath of fresh air and a serious and provocative challenge for creativity researchers (Glăveanu, 2014b). The implications of his argument are far-reaching. They resonate strongly with the need for a broader questioning of the epistemological foundations of academia today (AlhadeffJones, 2010; Bocchi \& Ceruti, 2004; Delors, 1996; Gidley, 2007; Giroux, 2010; McGregor \& Volckmann, 2011; Morin, Ciurana, \& Motta, 2003; Oliver \& Waldron Gershman, 1989). Glăveanu's article resonates strongly with my own research agenda, which has focused quite explicitly on the construction of knowledge, and specifically the construction of what we call creativity and creativity research (Eisler \& Montuori, 2007; Montuori, 2005a; 2011e; 2011f; Montuori \& Purser, 1995; 1996; 1999). Because of this strong resonance, I have taken the liberty of including a personal dimension to this reflection.

My introduction to the world creativity research was through the work of Frank Barron, who went on to become my mentor, colleague and dear friend. Frank saw himself as very much part of the larger community of the psychology of creativity. But he also admitted to me he was always viewed as a bit of an "odd fellow" by some of his peers, something he didn't see as entirely problematic, and perhaps even appropriate, given the subject 
(Barron, 1968, 1993). Barron was a founding member of IPAR where legendary studies of creativity employed a holistic approach, and was known for his psychometric research. But as he sometimes told me, with a twinkle in his eye, the larger community was perplexed and in some cases quite disapproving of his frequent references to the poet William Butler Yeats and to other non-psychologists. This was because Barron was not discussing Yeats just as a creator, as a subject of research, but also as a colleague, a fellow researcher in the psychology of creativity, engaged in explorations of the creative person and process. "Why does Barron cite poets instead of empirical research," his colleagues would wonder, sometimes in print. Equally disturbing to the community, it seems, were the liberal references to Bergson, Berdyaev, C.S. Peirce and other philosophers and artists who had explored creativity. It seems to me, that a community that celebrates "openness to experience" should not close itself off to these important sources and to important larger questions. As Glăveanu points out, the Creativity Research Journal's recent shift to requiring exclusively quantitative work, all of the time, is a sign of the times and not exactly heartening for those of us who like to draw on wider sources and now see most integrative work on creativity in the hands of journalists like Jonathan Lehrer and Steven Johnson, who are free to roam the literature without restrictions (Johnson, 2010; Lehrer, 2012). Glăveanu (2014, p. 13) writes that:

"Scholars seem to have abandoned the 'big' questions in favour of increasingly specialised inquiries leading them to develop subfields of a subfield (adding small bricks to an existing edifice) rather than contributing to our overall understanding of creativity" (consider the edifice itself).

This is an important critique that echoes the work of the French philosopher Edgar Morin (Morin, 2008a; 2008b; 1999) on transdisciplinarity, and a topic of considerable interest to me. Academia is also struggling with the mood of a postmodern suspicion of metanarratives, of any attempt to address the "big picture", coupled with a focus on the measurable, the empirical, and, of course, the brain! This has led, as Glăveanu points out, to a proliferation of more and more specialized research projects that mostly do not communicate with other projects, let alone most other people. In other words, academia is essentially a world of increasingly non-communicating hyper-specialized silos that are not integrated in larger frameworks (Taylor, 2009). This is a problem not limited to the psychology of creativity, as Morin has gone to great lengths to point out (Morin, 1990; 2001; 2008a; 2008b; 1999; Morin \& Kern, 1999; Morin \& Le Moigne, 1999). In 1993, for example, management theorist Jeffrey Pfeffer launched a strong and controversial critique of the excessive pluralism in his discipline, arguing that it should be ignored in favor of an 
agreement to set up a larger research agenda addressing fundamental questions (Pfeffer, 1993).

I agree with Glavenau that it is precisely these big questions concerning what he calls the edifice of creativity that need to be addressed. This includes the kinds of epistemological questions about the construction of knowledge and the relationship between theory and practice that have recently fallen out of favor. In our age of transition, creativity has become the subject of much attention. Futurists argue that the key competence for coping with our complex and troubled times is creativity. Creativity is now being hailed as a key competence for leaders, business is enamored with creativity and innovation and increasingly, sociologists are pointing to the importance of "creating" our lives: surely it is also time for creativity researchers to become more, not less, engaged with the larger discourse and explore the implications and applications of their work, as well as engage critically with the larger issue of how creativity is understood and applied (Bauman, 2005; 2007; Castells, 2000; Harman, 1998; Morin \& Kern, 1999; Sardar, 2010; Slater, 2008).

Compare the narrowness Glăveanu speaks of, with Frank Barron (1995, p. 6), situating his own research agenda:

"The psychology of the individual, the person, is the study of a world in itself. Yet, that world intersects and intermingles with the world of other individuals, so that very soon we must consider community, habitat, the intersection of the personal with cultural history, expectations of the future, and perhaps above all else in the human case, values and philosophy of life."

And again:

"The problem of psychic creation is a special case of the problem of novelty in all of nature. By what process do new forms come into being? The specification of the conditions under which novelty appears in human psychical functioning is the task to which the psychology of creativity addresses itself. In doing so, it links itself to the general scientific enterprise of describing the evolution of forms in the natural world" (Barron, 1969, p. 9).

The intellectual adventure Barron presents is "homeless" in a strictly disciplinary sense (Montuori, 2005a). It travels between disciplines, it moves across domains of knowledge, rather than remaining in a disciplinary box. Frank had a broad general culture that drew on philosophy, the subject of his undergraduate degree, literature and the arts, as well as the sciences. This broad background, something that is not encouraged in education today, coupled with his deep understanding of his own specialization, made his farreaching explorations so compelling and ahead of their time. Today there is perhaps even 
less of a place for this intellectual nomadism in the psychology of creativity than there was in Frank's day.

Glăveanu (2014, p. 12) further states that:

"Here lies perhaps one problem within the discipline: plenty of divergence and relatively little (constructive) accumulation. We seem to be asking every kind of question about creativity without listening enough to what others are doing or what they have found."

Compounding this problem is the eagerness in academia to use only the most recent references, to stay on top of the latest research, and often skip over the extensive research that has already been conducted, relegating it to being a matter of merely historical interest.

This increasing disciplinary hyper-specialization and fragmentation is surely one of the main reasons for Beghetto's concern that the psychology of creativity is not being used in education (Plucker, Beghetto, \& Dow, 2004), at a time when there is a real crisis of creativity in education (Lovitts, 2005; 2008; Montuori, 2011b; 2012; Robinson, 2001). The practitioner is faced with a profusion of interesting research papers and data points, but no real sense of how to apply this in the larger educational context, no framework within which to integrate, and no real sense of where all this relevant knowledge can even be found, because relevant research may be in the psychology of creativity, but also in educational research, sociology, and any number of other mostly non-communicating disciplines. Consequently new fields emerge, like "design," which explicitly address creativity, but often with minimal references to the research in the psychology of creativity. Moreover, before the emergence of transdisciplinarity there was no integrative discipline of disciplines, no framework for putting this all together let alone applying it. As another transdisciplinary thinker, Gregory Bateson (2002, p. 19) wrote:

"At present, there is no existing science whose special interest is the combining of pieces of information. But I shall argue that the evolutionary process must depend upon such double increments of information. Every evolutionary step is an addition of information to an already existing system. Because this is so, the combinations, harmonies, and discords between successive pieces and layers of information will present many problems of survival and determine many directions of change."

Over 10 years ago I designed a Master's in Leadership and a Transdisciplinary Ph.D. program at my institution based on the fundamental assumption that education can be a creative process (Montuori, 2010a; 2010b). Not surprisingly, this effort at the implementation and operationalization of creativity also led me to reflect on the larger questions of what creativity is in an academic context, how it can be fostered in the classroom, and 
so on. The very basic definitions of creativity were not sufficient: yes, a dissertation is supposed to be an original and useful contribution to one's field. In that very basic sense, the traditional definition applies. But really it only applies to the extent that it tells us the dissertation is, or should be - by definition! - a creative product. How does that translate into the everyday activities of the graduate student? Into the writing of a literature review (Montuori, 2005b; 2013)? It is a sad irony that even though the Ph.D. dissertation is supposed to be an original contribution to one's field, hardly any doctoral programs (or graduate programs) discuss creativity or the creative process. Plagiarism, on the other hand, gets a mention.

I have written elsewhere about the challenges of developing graduate programs that foster creativity, and I have proposed what I call "Creative Inquiry" as an approach to introducing creativity as central dimension of education (Montuori, 2006; 2008b; 2011a; 2011c; 2011d; Montuori \& Donnelly, 2013). Space does not permit me to explore this topic in detail, but I do want to focus on another aspect of my work in education, because it ties in very closely with Glăveanu's assessment of what is needed to revive creativity research. Glăveanu calls for us to delve more deeply into existing research and our paradigmatic assumptions as researchers. Expressing his concern for disciplinary fragmentation Glăveanu (2014, p. 13) states that:

"(T)his concern goes beyond simply referencing relevant literature, it refers to the need to make explicit one's paradigmatic assumptions."

Transdisciplinarity differentiates between disciplinary work, which is intra-paradigmatic, and where the assumptions of the discipline itself are hardly ever questioned, and transdisciplinary work, which involves an awareness and questioning of multiple sets of paradigmatic assumptions, including one's own, and requires the integration of the inquirer into the inquiry (Montuori, 2005a; 2008a; 2010a). Intra-disciplinary work is akin to what Kuhn called normal science (Kuhn, 1996). In other words, getting on with the problems of the established research agenda, within the mostly unquestioned established assumptions. There's nothing wrong with this, of course. As the physicist and transdisciplinary philosopher Nicolescu (2002, p. 122) states:

"The transdisciplinary method does not replace the methodology of each discipline, which remains as it is. Instead the transdisciplinary method enriches each of these disciplines, by bringing them new and indispensable insights, which cannot be produced by disciplinary methods."

Disciplinary research needs to be supplemented by a reflection on our individual, as well as our disciplinary and philosophical paradigmatic assumptions, and an integration of per- 
tinent knowledge from whatever sources are available for purposes of application.

Much of the popular creativity literature proposes following a step-by-step "how to" recipe, while ignoring, or at best cherry-picking from the vast research literature. A more informed application arguably requires a transdisciplinary approach. Applying creativity research to education requires an ability to integrate, draw from multiple relevant sources, and implementation by a specific person or persons in a specific context. I would argue that transdisciplinary scholar-practitioners may be akin to "para-professionals," inevitably not experts in all relevant specialized research fields, but more broadly oriented towards ongoing integration and application, an ongoing dialogue between theory and practice, between theorists and practitioners, and constantly seeking to enrich one with the other in the crucibles of experience and reflection (Ogilvy, 1977). This requires an orientation towards more practical, applied knowledge as well as a higher-level awareness of the construction of knowledge, found in the philosophy of social science. ${ }^{1}$

In summary, Glăveanu's rich and provocative essay is a call for a radical re-examination not only of the psychology of creativity, but of the entire academic enterprise. It challenges our disciplinary fragmentation, our increasing entrenchment within the quantitative and (lately) the neuro-scientific, and is a call for self-reflection, historical and contextual awareness, as well as a recognition of philosophical questions and frames, and above all a generative dialogue about these issues. This re-visioning of creativity will likely require the development of alternative spaces, journals, conferences, dialogues and explorations.

Glăveanu's own efforts at developing a cultural psychology of creativity and articulating the various paradigms of creativity, as well as the article discussed here, provide important steps in this direction (Glăveanu, 2010a; 2010b; 2011; 2014a; 2014b; Glăveanu \& Lubart, 2014). I can only hope that his work will stimulate further reflection as well as

\footnotetext{
${ }^{1}$ As I have argued elsewhere (Montuori, 2005a) that transdisciplinarity can be summarized as requiring four dimensions. A focus that is inquiry-driven rather than discipline driven. This does not involve a rejection of disciplinary knowledge, but the development of pertinent knowledge for the purposes of action in the world. In other words, it is the demands of our situation and application that guide our inquiry. A stress on the construction of knowledge through an appreciation of the meta-paradigmatic dimension - in other words, the underlying assumptions that form the paradigm through which disciplines and perspectives construct knowledge, and consequently the way various understandings of our situation are constructed. Disciplinary knowledge generally does not question its paradigmatic assumptions. An understanding of the organization of knowledge, isomorphic at the cognitive and the institutional level, the history of reduction and disjunction (what Morin calls "simple thought") and the importance of contextualization and connection (or "complex thought"). In a "live" situation of integration and application, where we draw on an ecology of ideas, we must go beyond analysis to bring in synthesis and take into account the networked phenomenon of interconnectedness. The integration of the knower in the process of inquiry, which means that rather than attempting to eliminate the knower, the effort becomes one of acknowledging and making transparent the knower's assumptions and the process through which s/he constructs knowledge.
} 
action in the development of a more open, distributed, integrative creativity research that is both theoretically richer as well as more aware of, and concerned with, practical applications.

\section{REFERENCES}

Alhadeff-Jones, M. (2010). Challenging the limits of critique in education through Morin's paradigm of complexity. Studies in Philosophy and Education, 29, 5, 477-490.

Barron, F. (1968). Creativity and personal freedom. New York: Van Nostrand.

Barron, F. (1993). Controllable oddness as a resource in creativity. Psychological Inquiry, $4,3,182-184$.

Bateson, G. (2002). Mind and nature: A necessary unity. Cresskill, NJ: Hampton Press. Bauman, Z. (2005). Liquid life. London: Polity Press.

Bauman, Z. (2007). Liquid times. Living in an age of uncertainty. London: Polity Press.

Bocchi, G. \& Ceruti, M. (2004). Educazione e globalizzazione [Education and globalization]. Milano: Raffaello Cortina.

Castells, M. (2000). The rise of the network society (New Edition). (The Information Age: Economy, Society and Culture Volume 1). New York: Wiley-Blackwell.

Delors, J. (1996). Learning: The treasure within. Report to UNESCO of the International Commission of Education for the Twenty-first Century. Paris: UNESCO.

Eisler, R. \& Montuori, A. (2007). Creativity, society, and the hidden subtext of gender: A new contextualized approach. World Futures. The Journal General Evolution, 63, 7, 479-499.

Gidley, J.M. (2007). Educational imperatives of the evolution of consciousness: the integral visions of Rudolf Steiner and Ken Wilber. International Journal of Children's Spirituality, 12, 2, 117-135.

Giroux, H.A. (2010). Education and the crisis of public values. New York: Peter Lang.

Glăveanu, V.P. (2010a). Paradigms in the study of creativity: Introducing the perspective of cultural psychology. New ideas in psychology, 28, 79-93.

Glăveanu, V.P. (2010b). Principles for a cultural psychology of creativity. Culture \& Psychology, 16, 2, 147-163.

Glăveanu, V.P. (2011). How are we creative together? Comparing sociocognitive and sociocultural answers. Theory \& Psychology, 21, 4, 473-492.

Glăveanu, V.P. (2014a). Distributed creativity: Thinking outside the box of the creative individual. New York: Springer.

Glăveanu, V.P. (2014b). The psychology of creativity: A critical reading. Creativity. Theories - Research - Applications, 1, p. 10-32, DOI: 10.15290/ctra.2014.01.01.02. 
Glăveanu, V.P. \& Lubart, T. (2014). Decentring the creative self: How others make creativity possible in creative professional fields. Creativity and Innovation Management, 23, 1, 29-43.

Harman, W.W. (1998). Global mind change: The promise of the last years of the 20th century. San Francisco: Berrett-Koehler.

Johnson, S. (2010). Where good ideas come from. The natural history of innovation. New York: Riverhead.

Kuhn, T. (1996). The structure of scientific revolutions (3d ed.). Chicago: University of Chicago Press.

Lehrer, J. (2012). Imagine. How creativity works. New York: Houghton Mifflin Harcourt.

Lovitts, B.E. (2005). Being a good course-taker is not enough: a theoretical perspective on the transition to independent research. Studies in Higher Education, 30 (April 2), 137-154.

Lovitts, B.E. (2008). The transition to independent research: Who makes it, who doesn't, and why. Journal of Higher Education, 79, 3, 296-325.

McGregor, S. \& Volckmann, R. (2011). Transversity: Transdisciplinary approaches in higher education. Tucson, AZ: Integral Publishers.

Montuori, A. (2005a). Gregory Bateson and the challenge of transdisciplinarity. Cybernetics and Human Knowing, 12, 1-2, 147-158, 112.

Montuori, A. (2005b). Literature review as creative inquiry. Reframing scholarship as a creative process. Journal of Transformative Education, 3(4), 374-393.

Montuori, A. (2006). The quest for a new education: From oppositional identities to creative inquiry. ReVision, 28, 3, 4-20.

Montuori, A. (2008a). Foreword. In B. Nicolescu (Ed.), Transdisciplinarity. Theory and practice (pp. IX-XVII). Cresskill, NJ: Hampton Press.

Montuori, A. (2008b). The joy of inquiry. Journal of Transformative Education, 6, 1, 8-27.

Montuori, A. (2010a). Research and the research degree: Transdisciplinarity and Creative Inquiry. In M. Maldonato \& R. Pietrobon (Eds.), Research on scientific research. A transdisciplinary study (pp. 110-135). Brighton \& Portland: Sussex Academic Press.

Montuori, A. (2010b). Transformative leadership for the 21st century. Reflections on the design of a graduate leadership curriculum. ReVision, 30, 3-4, 4-14.

Montuori, A. (2011a). Creative inquiry. In N.M. Seel (Ed.), The encyclopedia of the science of learning. Heidelberg: Springer.

Montuori, A. (2011b). Creativity in transformative education: An exploration in doctoral education. In M. Alhadeff-Jones \& A. Kokkos (Eds.), Transformative Learning in time of crisis: Individual and collective challenges: Proceedings of the 9th International Conference on Transformative Learning (pp. 204-210). Athens, Greece. 
Montuori, A. (2011c). Narcissistic learning. In N.M. Seel (Ed.), The encyclopedia of the science of learning. Heidelberg: Springer.

Montuori, A. (2011d). Reproductive learning. In N.M. Seel (Ed.), The encyclopedia of the science of learning. Heidelberg: Springer.

Montuori, A. (2011e). Social psychology. In M. Runco \& S. Pritzker (Eds.), The encyclopedia of creativity. Amsterdam: Elsevier.

Montuori, A. (2011f). Systems approach. In M. Runco \& S. Pritzker (Eds.), The encyclopedia of creativity (Vol. 2, pp. 414-421). San Diego: Academic Press.

Montuori, A. (2012). Creative Inquiry: Confronting the challenges of scholarship in the 21st century. Futures. The Journal of Policy, Planning and Future Studies, 44, 1, 64-70.

Montuori, A. (2013). The complexity of transdisciplinary literature reviews. Complicity: An International Journal of Complexity and Education, 10, 1/2, 45-55.

Montuori, A. \& Donnelly, G. (2013). Creative Inquiry and scholarship: Applications and implications in a doctoral degree. World Futures, 69, 1, 1-19.

Montuori, A. \& Purser, R. (1995). Deconstructing the lone genius myth: Towards a contextual view of creativity. Journal of Humanistic Psychology, 35, 3, 69-112.

Montuori, A. \& Purser, R. (1996). Context and creativity: Beyond social determinism and the isolated genius. A Rejoinder to Hale. Journal of Humanistic Psychology, 36, 2.

Montuori, A. \& Purser, R. (1999). Introduction. In A. Montuori \& R. Purser (Eds.), Social creativity (Vol. 1). Cresskill, NJ: Hampton Press.

Morin, E. (1990). Science avec conscience [Science with conscience]. Paris: Seuil.

Morin, E. (2001). Seven complex lessons in education for the future. Paris: UNESCO.

Morin, E. (2008a). On complexity. Cresskill, NJ: Hampton Press.

Morin, E. (2008b). The reform of thought, transdisciplinarity, and the reform of the university. In B. Nicolescu (Ed.), Transdisciplinarity. Theory and practice (pp. 23-32). Cresskill, NJ: Hampton Press.

Morin, E. (Ed.). (1999). Relier les conaissances: Le défi du XXle siècle [Reconnecting knowledge: The challenge of the 21st century]. Paris: Seuil.

Morin, E., Ciurana, E.R., \& Motta, R. (2003). Éduquer pour l'ère planétaire [Educating for the planetary era]. Paris: Balland.

Morin, E. \& Kern, B. (1999). Homeland Earth: A manifesto for the new millennium. Cresskill, NJ: Hampton Press.

Morin, E. \& Le Moigne, J.L. (1999). L'intelligence de la complexité [The intelligence of complexity.]. Paris: L'Harmattan.

Nicolescu, B. (2002). Manifesto of transdisciplinarity. Albany: SUNY Press. 
Ogilvy, J. (1977). Many dimensional man. New York: Harper.

Oliver, D.W. \& Waldron Gershman, K. (1989). Education, Modernity, and fractured meaning. Albany: SUNY Press.

Pfeffer, J. (1993). Barriers to the advance of organizational science: Paradigm development as a dependent variable. Academy of Management Review, 18, 4, 599-620.

Plucker, J.A., Beghetto, R.A. \& Dow, G.T. (2004). Why isn't creativity more important to educational psychologists? Potentials, pitfalls, and future directions in creativity research. Educational Psychologist, 39, 2, 83-96.

Robinson, K. (2001). Out of our minds: Learning to be creative. London: Capstone.

Sardar, Z. (2010). Welcome to postnormal times. Futures, 42, 5, 435-444.

Slater, P. (2008). The chrysalis effect. Brighton \& Portland: Sussex Academic.

Taylor, M. (2009, April 26). End of the university as we know it, New York Times. Retrieved from http://www.nytimes.com/2009/04/27/opinion/27taylor.html?_r=3\&smid=fbshare\&pagewanted=print

Corresponding author at: Alfonso Montuori, California Institute of Integral Studies 1453 Mission St. San Francisco, CA 94103 USA

E-mail: amontuori@ciis.edu 